\title{
Paradigma Pendidikan Agama Islam Berwawasan Multikultural dalam Menumbuhkan Sikap Toleransi Di SMP Negeri 4 Lamongan
}

\author{
Ahmad Hanif Fahruddin \\ Universitas Islam Lamongan \\ kanghanif88@unisla.ac.id
}

\section{Article History:}

Received: 09-02-2019

Revised: 22-02-2019

Accepted: 09-03-2019

\begin{abstract}
This research raises the problem of Islamic religious education with a multicultural perspective in fostering tolerance with subjects at SMP Negeri 4 Lamongan. In this study, several things will be examined, namely those related to the paradigm of Islamic religious education with a multicultural perspective and the urgency of Islamic religious education with a multicultural perspective in fostering tolerance. Researchers use qualitative methods and descriptive approaches. The results of the research succeeded in finding, among other things: the paradigm of Islamic religious education with a multicultural perspective obtained through a cognitive approach, experience and habituation approach, and through exemplary methods. Besides, Islamic education with a multicultural perspective also fosters a harmonious life attitude, respect, and respect, fosters a tolerant attitude and can create a learning climate and academic atmosphere in a conducive learning process and care for differences in productive ways.
\end{abstract}

Keyword: Islamic Religious Education, Multiculturalism, Tolerance

\section{Pendahuluan}

Indonesia adalah negara baru yang terbentuk dari komunitas-komunitas lama berupa kerajaan, komunitas budaya, kelompok suku, agama, dan sebagainya. Karena itu, Indonesia sering disebut sebagai bangsa yang majemuk (Plural). Indonesia merupakan negara yang terdiri dari beraneka ragam suku dan budaya. ${ }^{1}$

Multikulturalisme identik dengan keragaman kebudayaan. Menurut Parsudi Suparlan akar kata dari multikulturalisme adalah kebudayaan, yaitu kebudayaan yang dilihat dari fungsinya sebagai pedoman bagi kehidupan manusia. Dalam pembangunan bangsa, istilah miltikultural ini telah membentuk suatu ideologi yang disebut multikulturalisme. ${ }^{2}$ Pendidikan multikultural merupakan pendidikan yang memberikan kesempatan bagi seluruh anak bangsa untuk bersikap menghormati dan menghargai tanpa harus melihat perbedaan-perbedaan etnis, budaya dan agama yang dapat menjunjung tinggi martabat manusia tanpa harus melihat latar belakangnya.

Dari pemaparan diatas, maka pendidikan merupakan salah satu cara agar siswa dapat menjunjung tinggi nilai-nilai sosial dan juga untuk meningkatkan kehidupan sosial

${ }^{1}$ Benyamin Molan, Multikulturalisme Cerdas Membangun Hidup Bersama yang Stabil dan Dinamis (Jakarta: PT Indeks, 2019), 107.

${ }^{2}$ Muhammad Tholchah Hasan, Pendidikan Multikultural sebagai Opsi Penanggulangan radikalisme (Malang: Universitas Islam Malang, 2016), 7. 
yang damai. Pendidikan multikultural merupakan pendidikan yang memberikan kesempatan bagi seluruh anak bangsa untuk bersikap menghormati dan menghargai tanpa harus melihat perbedaan-perbedaan etnis, budaya dan agama yang dapat menjunjung tinggi martabat manusia tanpa harus melihat latar belakangnya.

Begitu juga dengan lembaga pendidikan atau sekolah, apabila dalam suatu lembaga pendidikan memiliki keanekaragaman budaya yang beragam maka akan menjadikan suasana menjadi lebih bernuansa. Hal ini dapat dilihat dari salah satu lembaga pendidikan yang memiliki keanekaragaman yaitu SMP Negeri 4 Lamongan. Berdasarkan observasi penulis, SMP Negeri 4 Lamongan merupakan lembaga pendidikan yang memiliki subyek-subyek pendidikan dengan latar belakang baik dari segi personal maupun komunal yang beragam. Menyadari akan hal tersebut, demi terciptanya kerukunan atau toleransi dalam setiap kegiatan sekolah dan pembelajaran, maka SMP Negeri 4 Lamongan sangat memperhatikan akan pendidikan multikulturalnya. Hal ini peneliti amati dari berbagai kegiatan yang dilakukan disekolah.

Salah satunya ialah kegiatan ekstrakulikuler, seperti ekstrakulikuler drumband, basket, volly fotsall, seni tari, paduan sura, pramuka. kegiatan tersebut dilakukan untuk memperluas pengalaman sosial dan juga untuk menjaga kerukunan atar siswa. Selain itu untuk menjaga pergaulan siswa, yang mana siswa yang berasal dari masyarakat asli lamongan, dapat bergaul dengan baik dengan anak yang bersal dari luar lamongan. ${ }^{3}$

Siswa-siwi SMP Negeri 4 Lamongan berasal dari berbagai latar belakang berbeda, ada yang dari Lamongan perkotaan, tidak sedikit pula dari Lamongan pinggiran (pedesaaan). Banyak juga yang berasal dari luar daerah Lamongan, serperi Gresik, Tuban, Jombang, Surabaya. Selain itu, siswa-siswi SMP Negeri 4 Lamongan ini bukan merupakan sekolah yang hanya di dominasi oleh anak-anak dari orang tua yang berstatus sosial tinggi saja, melainkan juga dari anak-anak yang berstatus sosial menengah kebawah seperti tukang becak, anak penjual nasi boran, dan lain sebagainya.

Lebih dari itu, perbedaan-perbedaan yang sering jelas terlihat adalah perbedaan ras atau kulit tubuh, ada anak yang berkulit putih dan ada juga anak yang berkulit hitam, pernah peneliti temui saat melakukan observasi anak yang berkulit hitam sedang di bully teman-temannya. Adanya perbedaan memang kerap kali menimbulkan kesenjangan. Namun karena adanya perbedaan inilah yang nantinya akan mempersatukan. Jadi, dari sinilah peran pendidikan agama Islam berwawasan multikultural di SMP Negeri 4 Lamongan sangat diperhatikan demi terciptanya sikap toleransi antar siswa.

Saat proses pembelajar mengajarpun berjalan dengan lancar, melalui pembelajaran pendidikan agama Islam (PAI) siswa saling berbagi ilmu. Guru PAI memberi kesempatan kepada siswa non Muslim untuk keluar kelas dengan syarat tidak boleh kemana-mana atau tetap dikelas, siswa non muslimpun memilih untuk tetap dikelas. Saat mengikuti pembelajaran siswa sangat antusias untuk mendengarkan,

\footnotetext{
${ }^{3}$ SMPN 4 Lamongan, Observasi, 11 November 2019
} 
terkadang siswa bertukar pikiran tentang kegiatan sehari-hari yang telah di ajarkan diagama masing-masing. Peran guru inilah untuk mengajarkan sikap toleransi. ${ }^{4}$

Adapun keadaan guru di SMP Negeri 4 Lamongan terutama guru PAI disini ada lima guru, terdiri dari dua guru wanita dan tiga guru laki-laki. Dimana masing-masing guru memiliki paham yang berbeda, ada yang tergolong NU ada pula yang Muhammadiyah. Memang terkadang terdapat kesenjangan, namun sikap toleransi antar satu sama lain selalu terjalin, yang muda menghormati yang tua dan yang tua menghargai yang muda. Pada intinya, kembali kepada peran dan tujuan sebagai guru yang profesional yang bisa menjadi teladan untuk murid-muridnya. ${ }^{5}$

Maka dari itu peran pendidikan Agama Islam disini sangat penting bagi kemajuan anak bangsa. Pendidikan Islam adalah bimbingan terhadap pertumbuhan rohani dan jasmani menurut ajaran Islam dengan hikmah mengarahkan, mengajarkan, melatih mengasuh mengawasi berlakunya agama Islam. ${ }^{6}$

Terkait dari penjelasan diatas, peneliti mengambil penelitian di SMP Negeri 4 Lamongan sebagai objek penelitian. Karena lembaga pendidikan ini sevcara meyakinkan mengimplemengtasikan nilai-nilai multikultural untuk menumbuhkan sikap toleransi, khususnya pendidikam agama Islam. Nilai-nilai multikulturral tersebut dapat menjadikan pendidikan sebagai memperkuat karakter di sekolah.

Penelitian ini menggunakan jenis penelitian kualitatif dengan pendekatan fenomenologi. Subjek penelitiannya adalah guru PAI, siswa SMP Negeri 4 Lamogan. Sumber dan jenis penelitiannya ada dua yaitu data primer dan data sekunder. Data primer data hasil wawancara dan data sekunderdata dari dokumentasi sekolah. Teknik pengumpulan data dalam penelitian ini menggunakantiga cara yaitu observasi, wawancara dan dokumentasi. Teknik analisis data dalam penelitian ini menggunakan tiga cara yaitu Reduksi data, Penyajian data dan Verifikasi. Pengecekan keabsahan datanya menggunakan triangulasi data, meliputi triangulasi sumber, triangulasi teknik dan triangulasi waktu. ${ }^{7}$

\section{Konsep Dasar Pendidikan Islam}

Pendidikan Islam secara etimologi berasal dari bahasa arab yaitu Trabiyah yang berarti "pendidikan", dengan kata kerja rabba. Sedangkan kata "pengajaran" dalam bahasa arabnya adalah ta'lim dengan kata kerja allama. Pendidikan dan pengajaran dalam bahasa arabnya tarbiyah wa ta'lim sedangkan pendidikan Islam dalam bahasa arabnya adalah tarbiyah, yang diderivasi dari kata rabba yang menununjukan untuk Tuhan, mungkin karena Tuhan juga bersifat mendidik, mengasuh, memeliharah, maha mencipta. ${ }^{8}$

Pendidikan Islam adalah proses transinternalisasi pengetahuan dan nilai-nilai Islam kepada peserta didik melalui upaya pengajaran, pembiasaan, bimbingan,

\footnotetext{
${ }^{4}$ Ahmad Bambang Mansyuro, Observasi, Lamongan, 11 November 2019.

${ }^{5}$ Zakiyah Yuliya Zulfah, Wawancara, Lamongan, 25 November 2019.

${ }^{6}$ Ramayulis, Ilmu Pendidikan Islam (Jakarta: Kalam Mulia, 2015), 37.

${ }^{7}$ Lexy J Meleong, Metodologi Peneliyian Kualitatif (Bandung: Reamaj Rosdakarya, 2017), 49.

${ }^{8}$ Zakiyah Drajat, Ilmu Pendidikan Islam (Jakarta: PT Bumi Aksara, 2016), 25-26.
} 
pengasuhan, pengawasan dan pengembangan potensinya, guna mencapai keselarasan dan kesempurnaan hidup di dunia dan di akhirat. ${ }^{9}$

Pendidikan agama Islam ialah pendidikan melalui ajaran-ajaran agama Islam yang berupa bimbingan dan asuhan terhadap anak didik agar nantinya setelah selesai dapat memahami, menghayati dan mengamalkan ilmu ajara islam yang telah diyakininya secara menyeluruh dan menjadikan ajaran agama Islam sebagai pandangan hidup demi keselamatan dan kesejahteraan hidup di dunia maupun di akhirat. ${ }^{10}$

\section{Dasar Pokok Pendidikan Agama Islam}

Dasar atau pondasi pendidikan Islam adalah al Qur'an dan Sunnah, karena keabasahan dasar ini sebagai pedoman hidup sudah mendapat jaminan Allah SWT dan Rasulnya. Nabi Muhammad sebagai pendidik pertama, pada masa awal pertumbuhan Islam telah menjadikan Al-Qur'an sebagai dasar pendidikan Islam disamping Sunnah beliau sendiri. ${ }^{11}$

Prinsip menjadikan Al-Qur'an dan Sunnah sebagai dasar pendidikan Islam bukan hanya dipandang sebagai kebeneran keyakinan semata. Lebih jauh kebenaran itu juga sejalan dengan kebenaran yang dapat di terima oleh akal yang sehat dan bukti sejarah. Dengan demikian barangkali wajar jika kebenaran itu kita kembalikan kepada pembuktian kebenaran pernyataan Allah SWT dalam Al-Qur'an.

Adanya dasar yang kokoh ini terutama karena Al-Qur'an dan Sunnah, merupakan pedoman hidup yang abadi, sebagai penjami keselamatan di dunia dan akhirat. Dasar Tambahan

\section{Tujuan pendidikan agama Islam}

Pendidikan agama Islam mempunyai tujuan-tujuan yang berintikan tiga aspek, yaitu aspek iman, ilmu dan amal, yang pada dasarnya berisi:

a. Menumbuh suburkan dan mengembangkan serta membentuk sikap positif dan disiplin serta cinta terhadap agama dalam perbagai ke hidupan anak yang nantinya di harapkan menjadi manusia yang bertakwa kepada Allah SWT taat kepada perintah Allah SWT dan Rosul-Nya.

b. Pengembangan pengetahuan agama di mungkinkan pembentukan pribadi yang berakhlak mulia, yang bertaqwa kepada Allah SWT, sesuai dengan ajaran agama Islam dan mempunyai keyakinan yang mantap kepada Allah SWT.

c. Menumbuhkan dan membina keterampilan beragama dalam semua lapangan hidup dan kehidupan serta dapat memahami dan menghayati ajaran agama Islam secara mendalam dan bersifat menyeluruh, sehingga dapat di gunakan sebagai pedoman hidup, baik dalam hubunggan dirinya dengan Allah, denggan sesama manusia dan dengan alam sekitar. ${ }^{12}$

\footnotetext{
9 Ramayulis, Ilmu Pendidikan Islam (Jakarta: Kalam Mulia, 2015), 38.

${ }^{10}$ Zakiyah Drajat

${ }^{11}$ Ibid., 188.

${ }^{12}$ Zakiyah Daradjat, Ilmu Pendidikan Islam (Jakarta: Bumi Aksara, 2016), 89-90.
} 


\section{Multikultural, Multikultalisme dan Pendidikan multikultural}

Tidak seorangpun di dunia ini yang dapat menolak sebuah kenyataan bahwa alam semesta adalah beragam, berwarna-warni dan berbeda-beda. Keragaman adalah hukum alam semesta atau sunatullah. Dengan kata lain keberagaman merupakan kehendak Allah dalam alam semesta. Al-Qur'an meyatakan dengan jelas mengenai hal ini dalam Q.S ar-Rum 22 :

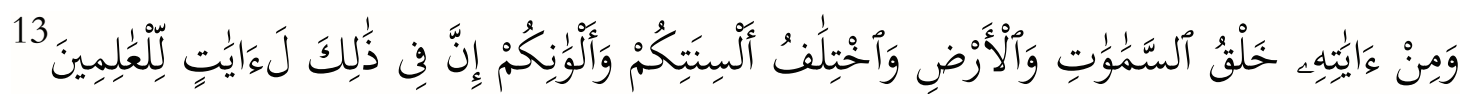

"Dan di antara tanda-tanda kekuasaan-Nya ialah menciptakan langit dan bumi dan berlain-lainan bahasamu dan warna kulitmu. Sesungguhnya pada yang demikan itu benar-benar terdapat tanda-tanda bagi orang-orang yang mengetahui."14

Maksudnya ialah di antara dalil-dalil kekuasaanNya adalah penciptaan langit, bumi, perbedaan bahasa dan dialek dan warna kulit manusia. Dari ayat inilah bisa dipahami, bahwa secara natural, eksistensi manusia merupakan makhluk multikultural. Ia diciptakan beragam dan hidup dalam keberagaman. Menolak perpedaan dalam hal apapun, sama halnya menolak dalil-dalil penciptaan. Secara etimologis, multikulturalisme di bentuk dari kata multi (banyak), kultur (budaya), dan isme (aliran atau faham). Sedangkan secara hakiki, dalam kata itu terkandung pengakuan akan martabat manusia yang hidup dalam komunitasnya dengan kebudayaannya masingmasing yang unik. ${ }^{15}$

Menyadari akan hal yang fitrah ini, merupakan dasar penting dalam membangun peradaban bangsa Indinesia. Sebuah kredo yang berbunyi: “dwi warna purwa, cendekia wasana" demikian Ki Hajar Dewantara mencerminkan kehendak untuk membangun manusia Indonesia yang memiliki sikap perilaku moral kebangsaan yang cintah tanah air, sadar akan hak, kewajiban serta profesional. Sikap ini dapat menjadi pengarah, penjamin upaya pembangunan agar agar tetap berada dalam rel yang benar, yakni rel kebangsaan Indonesia. Sikap perilaku warga negara yang cinta tanah air dan sadar hak dan kewajiban, salah satunya di upayahkan dalam pendidikan kewarganegaraan yang merupakan bagian integral upaya membangun sumber daya manusia. ${ }^{16}$

Menurut Lawrance Blum multikulturaslisme meliputi sebuah pemahaman, penghargaan dan penilaian atas budaya seseorang, serta sebuah penghormatan dan keingintahuan tentang budaya etnis lain. Multikuklturaslime meliputi sebuah penilaian tehadap budaya-budaya orang lain, bukan berarti menyetujui semua aspek dari budayabudaya tersebut, melainkan mencoba melihat bagaimana sebuah budaya yang asli dapat mengespresikan nilai bagi anggota-anggotanya sendiri. ${ }^{17}$

Al-Qur'an juga menekankan bahwa manusia di dunia, tanpa memandang perbedaan suku, dan ras disatukan dalam perlunya ketaatan mereka kepada satu Tuhan

\footnotetext{
${ }^{13}$ Al-Qur'an, 30: 22.

${ }^{14}$ Al-Qur'an dan Terjemahannya (jakarta : Alfatih), 406.

${ }^{15}$ Choirul Mahfud, Pendidikan Multikultural (Yogyakarta: Pustaka Pelajar), 75

16 Muhammad Tholchah hasan, Pendidikan Multikultural Sebagai Opsi Penanggulangan Radikalisme (Malang: Universitas Islam Malang, 2016), 1.

${ }_{17}$ Andre Ata Ujan, dkk, Multikulturalisme Belajar Hidup Bersama dalam Perbedaan (Jakarta: PT Indeks, 2009), 14.
} 
Sang Pencipta. Dalam ayat yang lain, al-Qur'an menekankan prinsip persatuan dalam perbedaan. Allah berfirman :

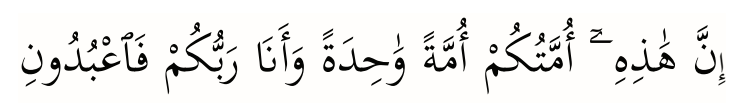

"Sesungguhnya (agama Tauhid) ini adalah agama kamu semua: agama yang satu dan Aku adalah Tuhanmu, maka sembahlah Aku."18 (Q.S. Al-Anbiya : 92).

Perbedaan sistem budaya membutuhkan dialog, bukan penggusuran dan penghancuran yang satu atas yang lain. Lembaga-lembaga pendidikan dan budaya dapat menjadi dialog, dengan cara mendorong diskusi yang jujur dan terbuka. Masyarakat atau manusia berkeharusan memperjuangkan kebebasan dan persamaan diatas perbedaanperbedaan budaya. Janji-janji dan harapan multikulturalisme bergantung keberhasilannya pada saling mendengar dan saling menghargai. ${ }^{19}$

Andersen dan Cusher berpendapat bahwa pendidikan Multikultural diartikan sebagai pendidikan mengenai keragaman kebudayaan. Sedangkan James Banks mendifinisihkan pendidikan multikultural sebagai pendidikan untuk people of color. Artinya, pendidikan multikultural ingin menyatukan perbedaan sebagai anugrah Tuhan. $^{20}$ Multikulturalisme di satu pihak merupakan suatu paham dan di lain pihak merupakan suatau pendekatan, yang menawarkan paradigma kebudayaan untuk mengerti perbedaan-perbedan yang selama ini ada di tengah-tengah masyarakat kita dan di dunia. ${ }^{21}$

Sebenarnya ada tiga istilah yang kerap di gunakan secara bergantian untuk menggambarkan masyarakat yang terdiri keberagaman tersebut baik keberagaman agama, ras, budaya, dan bahasa yang berbeda-beda yaitu plural (plurality), keberagaman (divercity), dan multikultural (multicultural). ${ }^{22}$

Dalam konteks pendidikan Multikultural, Gollnick and Chinn dalam Abdullah Aly mengemukakan terdapat setidaknya lima tujuan pendidikan multikultural. Tujuan ini juga menekankan isu-isu di atas batas-batas isu etnis dan ras. Tunjuan tersebut adalah:

1. Peningkatkan kekuatan dan keragaman budaya

2. Sebuah penekankan terhadap hak asasi manusia dan penghormatan kepada mereka yang berbeda dari lainnya.

3. Penerimaan terhadap alternatif kehidupan untuk manusia.

4. Mendorong keadilan sosial dan persamaan bagi semua manusia.

5. Sebuah penekanan terhadap distribusi kekuasaan dan income yang imbang di antara kelompok-kelompok manusia. ${ }^{23}$

${ }^{18}$ Al-Qur'an dan Terjemahannya (Jakarta : Alfatih), 330.

19 Muhammad Tholchah hasan, Pendidikan Multikultural Sebagai Opsi Penanggulangan Radikalisme (Malang: Universitas Islam Malang, 2016), 35.

${ }^{20}$ Ibid., 175.

${ }^{21}$ Andre ata Ujan, Multikulturaslime Belajar Hidup Bersama dalam Perbedaan (Jakarta, Indeks, 2009), 15.

${ }^{22}$ Mochamad Irfan, "Implementasi Pembelajaran Agama Islam Berwawasan Multikultural (Study Kasus di SMPN Bandar lampung)" (Tesis_-Universitas Negeri Raden Intan Lampung, 2018), 32.

23 Handayani, "Implementasi Pendidikan Agama Islam (PAI) Berwawasan Multikultural Dalam Membangun Toleransi Beragama di Sekolah Menengah Keatas Negeri 8 Malang” (Tesis-Universitas Islam Negeri Maulana Malik Ibrahim Malang, 2014), 35. 


\section{Paradigma Pendidikan Agama Islam Berwawasan Multikultural}

Pardigma adalah sebagai cara mendasar untuk mempersepsi, berfikir, menilai dan melakukan yang berkaitan dengan sesuatu secara khusus tengang visi realita. Hal ini sesuai dengan hasil wawancara yang peneliti paparkan sebelumnya, sebagai beikut:

a. Melalui pendektan kognitif

Bedasarkan teori Jean Piaget Pendekatan kognitif adalah suatu rancangan konseling atau pendekatan yang berfokus pada berfikir dan proses mental dalam modifikasih atau mengubah tingkah laku dan sering melibatkan pelatihan, pengembangan pemikiran, kontrol pikiran, serta proses-proses dan teknik-teknik yang berorientasi kognitif lainnya. ${ }^{24}$

Adapun Paradigma PAI berwawasan multikultural dalam menumbuhkan sikap toleransi di SMP Negeri 4 Lamongan juga memiliki pendekatan yang sama dengan teori tersebut, walau dengan istilah yang berbeda tapi mempunyai kandungan yang sama. Adapun pendekatan kognitif yang di berikan oleh guru PAI yaitu :

1) Di perkenalkan tentang hazanah pemikiran islam dari berbagai madzhab.

2) Di kenalkan dengan berbagai pemikiran para ulama zaman dahulu hingga zaman modern.

3) Di suguhkan berbagai literasi baik dari Al-Qur'an atau Hadits dan kitabkitab yang berhubungan dengan toleransi.

4) Menuangkan ide pemikiran dengan menghubungkan peristiwa yang terjadi dalam kehidupan sehari-hari yang berkaitan dengan sikap toleransi.

b. Melalui pendekatan pengalaman dan pembiasaan

Menurut perkembangan konstruktivisme anak secara aktif membangun pengetahuan dengan cara terus menerus mengasimilasi dan mengakomodasi informasi baru, dengan kata lain konstruktivisme adalah teori perkembangan kognitif yang menekankan kepada peran aktif siswa dalam membangun pemahaman mereka tentang realita. ${ }^{25}$

Dalam pembelajaran pendidikan agama Islam berwawasan multikultural di SMP Negeri 4 Lamongan, dimensi multikultural juga di perkenalkan dalam pendekatan pengalaman dan pembiasaan melalui peristiwa yang pernah di alami dalam kegiatan sehari-hari dalam jam pembelajaran atau di luar jam pembelajaran. Sesuai dengan hasil wawancara yang telah peneliti paparkan pada bab sebelumnya, ditemukan hasil:

1) Siswa diajak outdor learning ke berbagai tempat untuk mengobservasi, memahami, menganalisa dan menyimpulkan

\footnotetext{
${ }^{24}$ Sri Hartati, Pendekatan Kognitif Untuk Menurunkan Kecenderungan Perilaku Deliquensi Pada Remaja, Jurnal Humanis, Vol, IX No.2 (Agustus, 2012

${ }^{25}$ Trianto, Model Pembelajaran Trepadu Konsep, Strategi, dan Implementasinya dalam Kurikulum Tingkat Satuan Pendidikan (Jakarta, Bumi Aksara, 2014), 73.
} 
2) Siswa di berikan kesimpulan atau intisari yang di ambil hikmahnya sebagai pembelajaran di amsa yang akan mendatang

c. Melalui pendekatan keteladanan

Guru SMP Negeri 4 Lamongan dalam paradigma PAI berwawasan multikultural ditunjukan dalam interaksi antar guru dan siswa dalam proses pembelajaran. Guru-guru harus harus dapat menjadi panutan bagi para dengan memberi contoh saling menghargai dan menghormati antar semua guru tanpa diskriminatif daalam proses pembelajaran. Dengan adanya keteladanan guru, para siswa akan lebih mengerti bagaimana caranya bersikap dalam menghadapi perbedaan budaya.

Guru merupakan sebagai kunci keberhasilan bagi suatu lembaga pendidikan, guru sendiri dapat di katakan sebagai panutan bagi para siswanya. Dalam sebuah proses pembelajaran, sadar atau tidak, maka perilaku guru akan menjadi panutan yang pengaruhnya sangat besar terhadap siswanya. Perilaku ini akan menjadikan teladan bagi kehidupan sosial siswanya. Tugas seoarang guru tidak hanya sebagai penyalur ilmu saja tetapi, harus mampu sebagai panutan bagi siswa atau masyarakat.

Dalam pembelajaran PAI yang memiliki keberagaman khususnya bagi keberagaman siswa, maka proses pembelajaran harus di tekankan kepada pembangunan moral siswa. Oleh karena itu, seorang guru harus bisa menjadi teladan moral yang baik bagi siswanya. Pendidikan multikultural di katakan berhasil manakalah terbentuk pada diri siswa sebuah sikap toleran, tidak bermusahan dan menghargai setiap suku, ras, bahasa, adat istiadat, dan agama.

\section{Paradigma Multikulturalisme Guru PAI dan Siswa di SMP Negeri 4 Lamongan}

Bedasarakan pengertian persepsi menurut Leavitt Harold J persepsi dapat dilihat dalam arti sempit yaitu penglihatan bagaimana seseorang melihat sesuatu, sedangkan dalam arti luas ialah pandangan atau pengertian, yaitu bagaiamana seseorang atau mengartikan sesuatu. ${ }^{26}$ Sedangkan menurut Brian Fellow ialah persepsi yang memungkinkan suatu oraganisme menerima dan menganalisa informasi. ${ }^{27}$

Sesuai dengan pengertian tersebut persepsi guru dan siswa terhadap paradigma pendidikan agama Islam berwawasan multikultural dalam menumbuhkan sikap toleransi sebagai beikut:

\section{Menumbuhkan sikap hidup rukun}

Persepsi guru menumbuhkan sikap hidup rukun bukan hanya pada guru saja tetapi juga untuk seluruh siswa. Menumbuhkan sikap hidup rukun tidak hanya diwujudkan oleh guru SMP Negeri 4 Lamongan saja tapi, siswa-siswi juga

${ }^{26}$ Heriyanto, "Persepsi Masyarakat Terhadap Kualitas Pelayanan Publik Pada Bagian Administrasi Kesejahteraan Rakyat Pemerintah Kabupaten Gunung Kidul DIY” (Skripsi-Universitas Negeri Yogyakarta, 2014), 9 .

${ }^{27}$ Saiful Arif, "Persepsi Mahasiswa Terhadap Tayangan Realitis Show Mistik (Studi Kasusn Deskriptif pada Tayangan "Dua Dunia” ndi Trans7 pada Mahasiswa Ilmu Komunikasi UIN Sunan Kalijaga, 2015), 12. 
menerapkan hidup rukun baik dengan sesama siswa, siswa dengan guru dan dengan warga sekolah lainnya.

\section{Menumbuhkan sikap menghargai dan menghormati}

Dalam aktivitas pembelajaran PAI di SMP Negeri 4 Lamongan selalu mengajarkan hidup bersama, saling menghargai, saling menghormati antar satu dengan yang lain baik dari segi ras, bahasa maupun agama. Guru saling memberikan pemahan siswa tentang pentingnya sikap saling menghargai dan menghormati antar satu dengan yang dalam perbedaan. Ajaran Islam mengajarkan untuk saling bekerjasama dan saling tolong menolong dengan sesama manusia. Hal ini menggambarkan bahwa umat Islam di perintahkan untuk menjaga kerukunan umat beragama baik seagama maupun agama lainnya.

\section{Menumbuhkan sikap toleransi}

Dengan adanya sikap toleransi akan menumbuhkan sikap memahami dan menghargai orang lain. Dalam menumbuhkan sikap toleransi ini, guru SMP Negeri 4 Lamongan mengajarkan, membiasakan dan mencontohkan kepada siswa seperti: bersikap menghormati orang lain tanpa memandang suku, ras, agama, bahasa dan menerima perbedaan itu tetapi tidak ikut mengamalkan ajaran agama lain, akan tetapi hanya untuk menghormati keyakinan atau kepercayaan orang lain.

\section{Mendapakan pengetahuan}

Sekolah SMP Negeri 4 Lamongan merupakan sekolah yang multikultural hal ini, menjadikan siswa-siswi SMP Negeri 4 Lamongan mendapatkan pengalaman dan pengetahuan baik dari teman-teman, guru PAI, mapun dari kegiatan di luar sekolah.

\section{Urgensi Paradigma Pendidikan Agama Islam Berwawasan Multikultural dalam menumbuhkan sikap Toleransi}

Urgensi paradigma PAI berwawasan multikultural dalam menumbuhkan sikap toleransi di SMP Negeri 4 Lamongan sebagian besar bisa di lihat dari pengetahuan dan perilaku siswa dan guru dalam mengikuti prosedur pembelajaran dan pada saat guru memberikan wawasan pengetahuan tentang toleransi tersebut. Sebagaimana terdeskripsikan dalam temuan penelitian, dampak paradigma PAI berwawasan multikultural dalam menumbuhkan sikap toleransi adalah secara terus menerus menciptakan kondisi pembelajaran yang nyaman dan kondusif. Hal ini dikemudian hari, akan menyumbang tatanan masyarakat yang harmonis karena nilai-nilai toleransi sudah dikembangkan di lembaga pendidikan.

Pemetaan dan perlakuan yang baik terhadap difersitas siswa-siswi dan pengaturan kelas merupakan salah satu cara yang dapat di lakukan dalam menciptakan kelas yang kondusif. Siswa akan dapat belajar dengan baik dalam suasana belajar yang kondusif, yaitu suasana yang mendukung terklaksananya proses belajar mengajar yaang nyaman dan menyenangkan. Nyaman disini adalah jauh dari gangguan yang merusak konsentrasi belajar. Menyenangkan berarti suasana belajar yang gembira dan menyenangkan. Proses belajar yang kondusif ini akan menjadikan proses belajar mengajar yang optimal, yang memungkinkan siswa dapat memusatkan pikiran dan perhatiannya kepada apa yang sedang di pelajari. 
Urgensitas PAI berwawasan multikultural tersebut menjadikan suasana kekeluargaan yang ada di lingkungan sekolah lebih terasa, dimana hubungan guru dan siswa, guru dan orang tua, dan antara guru dengan guru yang lainnya yang dapat mencerminkan suasana yang harmonis, saling menghormati, saling menyayangi untuk pertumbuhan siswa. Salah satu wujud toleransi dalam keberagaman adalah menghormati perbedaan, menjalin hubungan sesama umat manusia dan silaturahmi antar umat untuk menjlin hubungan yang baik dengan umat lainnya. Secara hakikat, manusia itu sama yang membedakan hanya perilaku dan akhlak seseorang. Perbedaan seringkali menjadi pemicu masalah yang berlanjut menjadi konflik bila kita memahami, mengatasi dan menyikapnya dengan cara yang tepat. Maka dengan perbedaan, kita mampu merasakan makna kebersamaan, sehingga kita bisa memahami bahwa perbedaan tersebut menjadikan hidup lebih berarti.

\section{Kesimpulan}

Berdasarkan hasil penelitian tentang Paradigma Pendidikan Agama Islam Berwawasan Multikultural dalam Menumbuhkan Sikap Toleransi di SMP Negeri 4 Lamongan dapat di tarik kesimpulan bahwa paradigma pendidikan agama Islam berwawasan multikultural dalam menumbuhkan sikap toleransi di SMP Negeri 4 Lamongan di lakukan malalui pendekatan-pendekatan pembelajaran di kelas maupun di luar kelas yaitu dengan cara: a) melalui pendekatan kognitif, b) melalui pendekatan pengalaman dan pembiasaan, c) melalui pendekatan keteladanan. Urgensi pendidikan Islam multikultural dalam menumbuhkan sikap toleransi antara lain untuk: membangun persepsi guru tentang sikap toleransi, saling menghargai dan menghormati perbedaan yang ada, menumbuhkan sikap hidup rukun sehingga akan tercipta proses belajar kondusif dan memiliki sikap toleransi.

\section{Daftar Rujukan}

Aji Nugroho Muhammad, "Konsep Pendidikan Islam Berwawasan Kerukunan pada Masyarakat Multikultural", Jurnal Studi Agama, Vol. 17, No. 2, 2018.

Aji Nugroho Muhammad, "Pendidikan Islam Berwawasan Multikultural; sebuah Upaya Membangun Pemahaman Keberagaman Insklusif pada Umat Muslim", Jurnal kajian Pendidikan Islam, Vol. 08, No. 1, Juni, 2016.

Al-Qur'an dan Terjemahannya. Jakarta: Alfatih.

Ata Ujan Andre, dkk, Multikulturalisme Belajar Hidup Bersama dalam Perbedaan. Jakarta: PT Indeks, 2009.

Aunir Rohman, Moh. "Dengan judul Internalisasi nilai-nilai agama islam dalam pembinaan mental santri melalui metode pembiasaan di Pondok Pesantren Darul Fiqh Deket Lamongan." Skripsi-Universitas Islam Lamongan,2019.

Daradjat Zakiyah, dkk, Ilmu Pendidikan Islam. Jakarta: PT Bumi Aksara, 2016.

Destiannisa Ayugi, "Implementasi Metode pendekatan Kognitif dalam Pembelajaran Paduan Suara", Jurnal Harmonia, Vol.12, No. 2, Desember, 2012.

Dwi Candra, Rini. "Dengan judul peran guru agama dalam meningkatkan kerukunan siswa antar agama di SMA selamat pagi Indonesia batu." Skripsi-Universitas Islam Negeri Maulana Malik Ibrahim Malang, 2015. 
Handayani, "Implementasi Pendidikan Agama Islam (PAI) Berwawasan Multikultural Dalam Membangun Toleransi beragama Di Sekolah Menengah Keatas Negeri 8 Lamongan". Skripsi- - Universitas Islam Negeri Maulana Malik Ibrahim Malang, 2014.

Imadudin rahmat M, Islam Pribumi : mendialogkan Agama membaca realitas. Jakarta: Erlangga, 2003.

Irfan Mohammad, "Implementasi Pembelajaran Agama Islam Berwawasan Multikultural (Study Kasus di SMPN Bandar lampung)”, Tesis-Universitas Negeri Raden Intan Lampung, 2018.

Kaelan, Pendidikan Pancasila. Yogyakarta: Paradigma, 2014.

Kristianto Adi, "Hubungan Lingkungan Belajar dengan Prestasi Belajar siswa Kelas II Jurusan Teknik Mekanik Otomotif SMK Se-Kabupaten Sleman", SkripsiUniversitas Negeri Yogyakarta, 2012.

Lailatul Mubarokah Nur, "Integrasi nilai-nilai multikultural dalam pembelajaran pendidikan agama Islam (PAI) siswa kelas XI di SMA Negeri 3 Bantul”, SkripsiUniversitas Islam Negeri Sunan KalijagaYogyakarta, 2003.

J. Moleong Lexy, Metodologi Penelitian Kualitatif . Bandung: PT Remaja Rosdakarya, 2017.

Hakim, Lukman, "Dengan judul Internalisasi nilai-nilai agama islam dalam pembentukan sikap dan perilaku siswa Sekolah Dasar Islam Terpadu AL-Muttaqin kota Tasikmalaya", Jurnal Pendidikan Agama Islam, Vol. 10, No. 1. 2012.

Mahfud Choirul, Pendidikan Multikultural, Yogyakarta: Pustaka Pelajar, 2016.

Molan Benyamin, Multikulturalisme Cerdas Membangun Hidup Bersama yang Stabil dan Dinamis. Jakarta: PT Indeks, 2019.

Muri Yusuf A, Metode Penelitian Kuantitatif, Kualitatif \& Penelitian Gabungan. Jakarta: Kencana, 2017.

Musrawi Zuhairi, Al-Qur'an Kitab Toleransi, Jakarta: Pustaka Oasis, 2007.

Nur Hidayat Sidiq, "Penerapan Pembelajaran Konstruktivistik Untuk Meningkatkan Prestasi dan Keaktifan Belajar Sswa Pada mata Pelajaran Tune-Up Motor Bensin Kelas IX di SMK Muhammadiyah Cawas", Skrpsi-Universitas Negrei Yogyakarta, 2015.

Putri Juwita Yuli, "pengembangan nilai-nilai Multikultural dalam Pembelajaran Pendidikan Agama Islam di SMA Taman Madya ibu Pawiyatan Taman Siswi Yogyakarta". Skripsi- -Universitas Islam negeri Sunan Kalijaga, 2017.

Ramayulis, Ilmu Pendidikan Islam, Jakarta: Kalam Mulia, 2015.

Sugiyono, Metode Penelitian Kuantitatif, Kualitatif, dan R\&D. Bandung: Alfabeta, 2015.

Susanto Ahmad, Teori Belajar dan Pembelajaran di sekolah Dasar, Jakarta: Pramedia Group, 2016.

Tafsir Ahmad, Ilmu Pendidikan Islami, Bandung: Remaja Rosdakarya, 2013.

Tholchah Hasan Muhammad, Pendidikan Multikultural sebagai Opsi Penanggulangan radikalisme. Malang : Universitas Islam Malang, 2016.

Trianto, Model Pembelajaran Trepadu Konsep, Strategi, dan Implementasinya dalam Kurikulum Tingkat Satuan Pendidikan, Jakarta, Bumi Aksara, 2014.

Ulfa, Aunia, "Dengan judul internalisasi nilai-nilai toleransi beragama melalui pembelajaran agama islam di SD Negri 1 Ngadas Malang". Skripsi-Universitas Muhammadiyah Malang,2019.

Usman Muhammad, "Internalisasi nilai-nilai toleransi dalam pembelajaran pendidikan agama islam di SMA Negeri 1 Lhokseumawe, Aceh, Indonesia", Jurnal Of Islamic Education, Vol. 2, No. 1, 2019. 